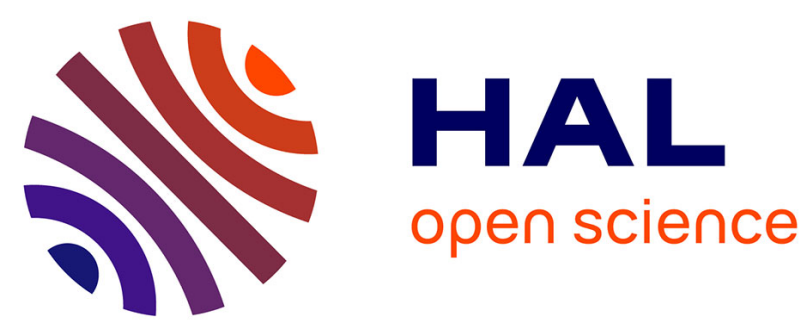

\title{
Potential Improvement of Building Information Modeling (BIM) Implementation in Malaysian Construction Projects
}

Aryani Ahmad Latiffi, Suzila Mohd, Umol Syamsyul Rakiman

\section{To cite this version:}

Aryani Ahmad Latiffi, Suzila Mohd, Umol Syamsyul Rakiman. Potential Improvement of Building Information Modeling (BIM) Implementation in Malaysian Construction Projects. 12th IFIP International Conference on Product Lifecycle Management (PLM), Oct 2015, Doha, Qatar. pp.149-158, 10.1007/978-3-319-33111-9_14. hal-01377439

\author{
HAL Id: hal-01377439 \\ https://hal.inria.fr/hal-01377439
}

Submitted on 7 Oct 2016

HAL is a multi-disciplinary open access archive for the deposit and dissemination of scientific research documents, whether they are published or not. The documents may come from teaching and research institutions in France or abroad, or from public or private research centers.
L'archive ouverte pluridisciplinaire HAL, est destinée au dépôt et à la diffusion de documents scientifiques de niveau recherche, publiés ou non, émanant des établissements d'enseignement et de recherche français ou étrangers, des laboratoires publics ou privés. 


\title{
Potential Improvement of Building Information Modeling (BIM) Implementation in Malaysian Construction Projects
}

\author{
Aryani Ahmad Latiffi ${ }^{1}$, Suzila Mohd ${ }^{2}$, Umol Syamsyul Rakiman ${ }^{3}$ \\ ${ }^{1,2,3}$ Faculty of Technology Management and Business, Universiti Tun Hussein Onn \\ Malaysia (UTHM), 86400 Batu Pahat Johor, Malaysia \\ 1aryani@uthm.edu.my, ${ }^{2}$ suzilamohd@gmail.com, ${ }^{3}$ avid8787@yahoo.com
}

\begin{abstract}
Application of building information modeling (BIM), such as preview design clashes and visualize project's model increase effectiveness in managing construction projects. However, its implementation in Malaysian construction projects is slow in order to see and gain the benefits. Therefore, this paper aims to explore on potential improvement that could increase BIM implementation in construction projects. A literature review was conducted in the history of BIM and its effects on construction projects in Malaysia. This is further supported by semi-structured interviews with construction players, consist of client, architect, structural engineer, mechanical, electrical and plumbing (MEP) engineers as well as contractor to discover potential improvement that could increase BIM implementation in construction projects. Encouragement from the government and top managerial level in an organization were found as a way to increase BIM implementation in construction projects. Highlighting the potential improvement is expected to increase BIM implementation in construction projects.
\end{abstract}

Keywords: Building Information Modeling (BIM), Construction industry, Construction project, Improvement, Malaysia

\section{Introduction}

Building Information Modeling (BIM) is a method, which involves the use of technology to improve collaboration and communication of construction players as well as documentation management [1]. Moreover, BIM is also known as a combination of process and technology to improve efficiency and effectiveness of delivering a project from inception to operation and maintenance [2]. BIM implementation in construction projects had been used by architectural, engineering and construction or facility management (AEC/FM) to manage construction project life-cycle. It also improves communication and collaboration among construction players in order to increase efficiency and effectiveness in managing construction projects. BIM implementation in the construction industry has been spread widely in the United States of America (USA), Hong Kong (HK), Australia, [3], [4] Singapore 
[5], [6] and Malaysia [6], [7], [8]. However, the implementation of BIM in the Malaysian construction industry is relatively new [7], [9].

There are many efforts undertaken by the Malaysian government in order to increase BIM implementation in construction projects. The government sectors, which is Construction Industry Development Board (CIDB) and Public Works Department (PWD) have promoted and encouraged construction players to implement BIM [9], [10]. CIDB has organized several seminars and preparing BIM roadmap as well as guideline as a way to promote BIM [8], [9], [10]. The purpose of organizing BIM seminars is to give exposure on benefits of BIM implementation in construction projects. Meanwhile, the purpose of preparing BIM roadmap and guidelines is to assist construction players to implement BIM in construction projects [8], [9], [10].

Apart from that, PWD had established a group of BIM committee to identify construction project process that involved with BIM implementation [9], [10], [11]. The committee also prepared a BIM standard manual documentation as a guideline for construction players reference in managing Malaysian government projects [9], [10], [11]. Moreover, there were several BIM pilot projects, which have been monitored by PWD such as NCI project, Type 5 Clinic (KK5) Sri Jaya Maran, Pahang and Administration Complex of Suruhanjaya Pencegah Rasuah Malaysia (SPRM) Shah Alam, Selangor [6], [9], [12]. The purpose of running BIM pilot projects is to test the capability of the PWD committee to manage projects using BIM [12].

Although there are many efforts done by the Malaysian government to increase BIM implementation in construction projects [9] however, BIM implementation is still slow and less favorable [7]. Therefore, this paper seeks to investigate barriers and challenges to implement BIM as well as potential improvements from BIM practitioner in Malaysia in order to increase BIM implementation in construction projects.

\section{Methodology}

Data for this paper is gained through literature review and semi-structured interviews. Both methods were used to gather information on BIM implementation in Malaysian construction projects. A Literature review was conducted to gather information on the history of BIM and BIM effects on Malaysian construction projects. All information on BIM was gathered from books, journal articles, international conference papers and materials available on the internet. Moreover, the semi-structured interviews were made with construction players, which all of them have been involved and currently involved in projects using BIM in Malaysia. Due to insignificant number of projects using BIM, limitation of BIM expertise, little evidence to show the percentage of construction players have implemented BIM in Malaysian construction projects [7] and most of BIM project has been monopolized by the same construction players, only (8) respondents were involved in this paper. The respondents' selection were based on their willingness to cooperate and share their experiences in managing projects using BIM. The respondents are client, structural engineer, mechanical and electrical (M\&E) engineer and contractor. Data 
from the semi-structured interviews revealed potential improvements to increase BIM implementation in Malaysian construction projects. All data from the interviews were recorded, transcribed and analyzed using content analysis. All findings are represented through text, tables and expression so that the data are easily understood. The next section will discuss on results and findings from the interviews.

\section{$3 \quad$ Results and Findings}

This section discusses on data gained from the semi-structured interviews with construction players, which are client, architect, structural engineer, M\&E engineer and contractor. There are five (5) parts in this section as follows:

\subsection{Respondent's Background}

There were eight $(8)$ respondents involved in the semi-structured interviews. The respondents consist of BIM principal director, BIM coordinator, client, structural engineer, M\&E engineer as well as architect. Table 1 shows the respondent's background.

Table 1. Respondent's Background.

\begin{tabular}{llll}
\hline Respondent & Position in Project Using BIM & $\begin{array}{l}\text { Experience in } \\
\text { Project Using } \\
\text { BIM (Year) }\end{array}$ & $\begin{array}{l}\text { No. of Project } \\
\text { Using BIM }\end{array}$ \\
\hline R1 & BIM principal director & 6 & 3 \\
R2 & BIM coordinator & 4 & 2 \\
R3 & Contractor/Project manager & 3 & 3 \\
R4 & BIM coordinator & 4 & 4 \\
R5 & Client & 5 & 2 \\
R6 & Structural engineer/client & 3 & 4 \\
R7 & M\&E engineer/client & 3 & 2 \\
R8 & Architect/client & 4 & 4 \\
\hline
\end{tabular}

Based on Table 1, the indicators of $\mathrm{R} 1$ to $\mathrm{R} 8$ is the representation of the respondents. All respondents have more than 3 to 6 years of experience in managing project using BIM. All respondents were responsible in managing project design in construction project using BIM in more than 2 projects. Furthermore, all respondents also responsible for residential and commercial building projects. Based on the respondents' position and experiences in project using BIM, it is reasonable to conclude that all respondents have knowledge on BIM implementation in construction projects. This is because, personal experience is the essential element in knowledge creation [13]. Therefore, the longer the experiences of the respondents in projects using BIM, the greater their understanding and knowledge on BIM implementation in construction projects. 


\subsection{Understanding on BIM}

The aim of this part is to discuss on knowledge and understanding on BIM among construction players in construction projects. Generally, all respondents shared a similar understanding that BIM is a process to improve project design. BIM is used in improving the process of managing project design. Table 2 shows understanding of the respondents on BIM.

Table 2. Understanding on BIM.

\begin{tabular}{|c|c|}
\hline Respondent & Annotation \\
\hline $\mathrm{R} 1$ & $\begin{array}{l}\text { 'BIM is a process to manage construction project life-cycle. All information } \\
\text { on project design can be used for whole project life-cycle by construction } \\
\text { players'. }\end{array}$ \\
\hline $\mathrm{R} 2$ & $\begin{array}{l}\text { BIM is a new method (process) in project design, which consists of all } \\
\text { information for a construction project. All the information can be obtained } \\
\text { from a } 3 D \text { model, which can be used by all construction players involved in } \\
\text { the same project'. }\end{array}$ \\
\hline R3 & $\begin{array}{l}\text { 'BIM basically a process that brings all data or information on project } \\
\text { design (architecture, structural and } M \& E \text { design) together in one parametric } \\
\text { model. That means, we do not have to produce the design separately'. }\end{array}$ \\
\hline $\mathrm{R} 4$ & $\begin{array}{l}\text { BIM is an art for project model, and the model must consists of all } \\
\text { information on project design and the most important is the design team } \\
\text { should know how to insert, manage as well as use all the data or information } \\
\text { in the parametric model'. }\end{array}$ \\
\hline R5 & $\begin{array}{l}\text { 'BIM is a process to facilitate construction projects effectively. The usage of } \\
\text { BIM in construction projects has reduced problems in construction stage'. }\end{array}$ \\
\hline R6 & $\begin{array}{l}\text { 'BIM is a method or process to develop designs for a construction project. } \\
\text { We can detect design clashes earlier and reduce construction problems } \\
\text { during construction stage'. }\end{array}$ \\
\hline R7 & $\begin{array}{l}\text { 'BIM is a process to develop project design and increase collaboration } \\
\text { among construction players'. }\end{array}$ \\
\hline $\mathrm{R} 8$ & $\begin{array}{l}\text { 'BIM is a process, which involved } 3 D \text { parametric model components, } \\
\text { parametric and can be analyzed'. }\end{array}$ \\
\hline
\end{tabular}

Based on the table, R1 understood that BIM can be used to manage construction project life-cycle. R1 also explained that, BIM allowed all information in project design to be used in whole project life-cycle. Moreover, it can also be referred by Quantity Surveyor (QS), project planner and facility manager to manage their task.

Apart from that, three (3) respondents (R3, R4 and R8) explained that BIM is a process, which consists of a parametric model. The parametric model is a $3 \mathrm{D}$ model, which consists of all information regarding a construction project. They also mentioned that, the model can be analyzed prior to the construction process in order to avoid construction problems. All information in the model will be used to manage whole project life-cycle.

Moreover, R2 and R7 understood that BIM is a method or process to manage construction projects activities especially project design. R2 explained that, BIM implementation in project design includes all information regarding a project in one model, which is a 3D model. The model then can be used and referred by whole 
construction players involved in the project. Meanwhile, R7 also explained that BIM implementation increases collaboration among construction players especially design team.

Two respondents (R5 and R6) agreed that BIM is a process to facilitate construction projects. Both respondents believed that BIM is an effective process in managing construction projects by reducing construction problems such as design clashes, design changes during construction stage, project delays, and construction cost overruns. Therefore, it can be concluded that, BIM implementation in construction projects has increased efficiency and effectiveness in managing whole project life-cycle with the help of 3D parametric model. The 3D model will consist all information regarding a project, which all construction players in a project can refer to same model in order to execute the project. Therefore, it can increase communication and collaboration among them, where all construction problems, for example, design clashes could be resolved earlier during pre-construction stage by visualizing the model.

\subsection{Effect of BIM Implementation in Construction Projects}

The aim of this part is to investigate effects of BIM implementation in construction projects. All respondents gave a positive response on effects of BIM implementation in construction projects. They agreed that BIM implementation in project design gives benefits to construction projects in terms of time, cost and quality. The ability of BIM to produce design clashes analysis during design stage helps design team to solve the design clashes early in pre-construction stage. Therefore, it could avoid project delay and construction cost overrun.

Moreover, all respondents agreed that the ability of 3D model to visualize project design increases client satisfaction and understanding regarding project design. Therefore, the client can make faster decision regarding the project design and avoid design changes during design stage. The visualization is an abstraction of the object or idea [14] and it could increase client understanding by viewing the project design model. Apart from that, the semi-structured interviews revealed that, BIM could accelerate the project design process $70 \%$ faster than conventional process. As a result, construction cost can be sustained as the project meets the deadline or shorter than it should be.

Thus, all respondents explained that BIM implementation in construction projects can increase effectiveness in managing project design and site coordination. The $3 \mathrm{D}$ model helps contractor to manage site coordination effectiveness, where the 3D model can visualize the actual site condition. Site engineer can arrange the site condition clearly and orderly by using the 3D model. The arrangement of each material and machinery in construction site became more organized by using a 3D model [15]. The visualization from 3D model helps contractor to manage site coordination effectiveness.

Furthermore, a safety officer can also refer to the same 3D model to analyze construction hazard by visualizing the site condition. It can helps safety officer to prepare an effective safety plan in construction site in order to avoid construction site accident. A proper safety plan is important in order to reduce the probability of 
construction site accident [16], [17]. Table 3 shows the positive effects of BIM implementation in construction projects.

Table 3. Positive effects of BIM Implementation.

\begin{tabular}{lll}
\hline No & Factors & Benefits \\
\hline 1 & Time & Faster decision making and producing project design. \\
& & Earlier clash detection in design stage. \\
& Reduce construction time to complete project design. \\
& & Avoid data or information lost. \\
\hline 2 & Cost & Avoid cost overrun. \\
\hline 3 & Quality & $\begin{array}{l}\text { Increases effectiveness in managing site coordination. } \\
\end{array}$ \\
& Increase communication and collaboration among design team. \\
& Increases quality of a construction project by reducing construction \\
& problems. \\
& Avoid accident in construction site.
\end{tabular}

The effectiveness of BIM in avoiding project delay and sustaining construction cost had increased the quality of construction projects. This is because, most of construction problems such as design clashes and data lost regarding a project had been solved earlier in pre-construction stage and bring successful to the project during construction stage.

\subsection{Factors Contribute to Barriers and Challenges to Implementing BIM}

The aim of this part is to investigate factors that contribute to barriers and challenges of BIM implementation in construction projects. There are several factors and causes contributed to barriers and challenges of BIM implementation in construction projects. All respondents agreed that, the main factors that contribute to the barriers and challenges to implement BIM in construction projects are people, process and technology. This is in line with findings from literature review, which claimed that people, process and technology can be the barriers and challenges in implementing BIM in construction projects [18].

The first factor that contributes to barriers and challenges to implement BIM in construction projects is 'people'. 'People' here means construction players. All respondents agreed that, most of the construction players refused to implement BIM because they are comfortable with traditional or conventional process in managing construction projects. Lack of knowledge and skill on BIM also one of the factors contributing to slow implementation of BIM among the construction players. Moreover, lack of awareness on BIM and encouragement to implement BIM among clients and top managerial in construction organizations contribute to the lack of knowledge and skill on BIM among the construction players [3], [19].

The second factor which contributes to barriers and challenges of BIM implementation in construction projects is 'process'. All respondents mentioned that a guideline on BIM is important to assist construction players to implement BIM in construction projects. Without a proper guideline, BIM implementation process could be false and it causes the construction players fail to obtain benefits of BIM. Apart 
from that, many construction players have developed their own version of BIM implementation guideline [7]. However, their own guideline somehow has resulted in confusion among construction players, which render the construction players to feel doubted to implement BIM [7], [8]. This matter led to the slow adoption of BIM in construction projects because most of construction players refuse to implement BIM in their next construction projects.

The last factor contributing to barriers and challenges of BIM implementation in construction projects is 'technology'. All respondents agreed that, to adopt a new technology such as BIM requires high cost. The cost to adopt new hardware (computer), software (BIM tools) and BIM training are expensive [3], [20], [21]. All respondents agreed that, the total amount to implement BIM in a construction organization could reach RM $15,000.00$ to RM 90,000.00, which only large organizations can afford. Construction players need to invest around RM 15,000.00 only to adopt BIM tools, meanwhile to adopt new hardware such as computer to support BIM tools and BIM training could reach to RM 90,000.00.

Combinations of all these factors results in the slow implementation of BIM among the Malaysian construction projects in general. Table 4 shows the summary of barriers and challenges of BIM Implementation in construction projects.

Table 4. Barriers and Challenges of BIM Implementation.

\begin{tabular}{lll}
\hline No & Factors & Barriers and Challenges \\
\hline 1 & People & $\begin{array}{l}\text { Comfortable with traditional process made construction players refuse to } \\
\text { change. } \\
\end{array}$ \\
& $\begin{array}{l}\text { Lack of knowledge of BIM. } \\
\text { Lack of skill on BIM. }\end{array}$ \\
\hline 2 & Process & $\begin{array}{l}\text { No BIM guideline and specific model could assist construction players to } \\
\text { implement BIM. }\end{array}$ \\
\hline 3 & Technology & BIM tools are expensive. \\
& & New hardware is expensive. \\
& BIM training is expensive. \\
\hline
\end{tabular}

\subsection{Potential Improvement of BIM Implementation in Construction Projects}

The aim of this part is to investigate potential improvement to overcome the barriers and challenges of BIM implementation in construction projects. All respondents have suggested several potential improvements in order to overcome barriers and challenges of BIM implementation in managing construction projects. There are seven (7) potential improvements revealed from the semi-structured interviews.

All respondents agreed that early understanding on BIM among top managerial in organization is important to increase BIM implementation in construction projects. Top managerial plays a significant role in order to increase BIM implementation in construction projects [3], [14]. The top managerial deserve the right in deciding to implement BIM in an organization in order to manage their projects. Moreover, top managerial also has full authority to encourage or to force their staff to implement BIM. Apart from that, early understanding by top managerial could also facilitate 
their staff to undergo training on BIM and also facilitate BIM implementation process in an organization.

Apart from that, all respondents also agreed that, the Malaysian government should provide a guideline on BIM to assist BIM implementation in construction projects among construction players. The guideline will assist construction players the right process to implement BIM in construction projects [7], [8]. Apart from that, all respondents agreed that an approach model to implement BIM is required to assist construction players especially for the beginner to implement BIM. A strategic approach model to implement BIM is needed in order to assist construction players [7].

Last and but not least, all respondents explained that cooperation between BIM practitioner, academia and researcher can give early exposure on BIM to undergraduate and postgraduate student. Their cooperation could increase knowledge and skill on BIM among the students. It can be done by creating one added syllabus on BIM in academic menu. Hence, students will be familiar with the BIM process, its tools and more prepared in their future career. This is because, BIM will become one of requirement for students in order to get involved in the construction industry. Moreover, the cooperation among BIM practitioner, academia and researcher can increase awareness on BIM by sharing information on BIM through publishing articles in several publications. Table 5 shows the potential improvements stated by the respondents.

Table 5. Potential Improvements of BIM Implementation

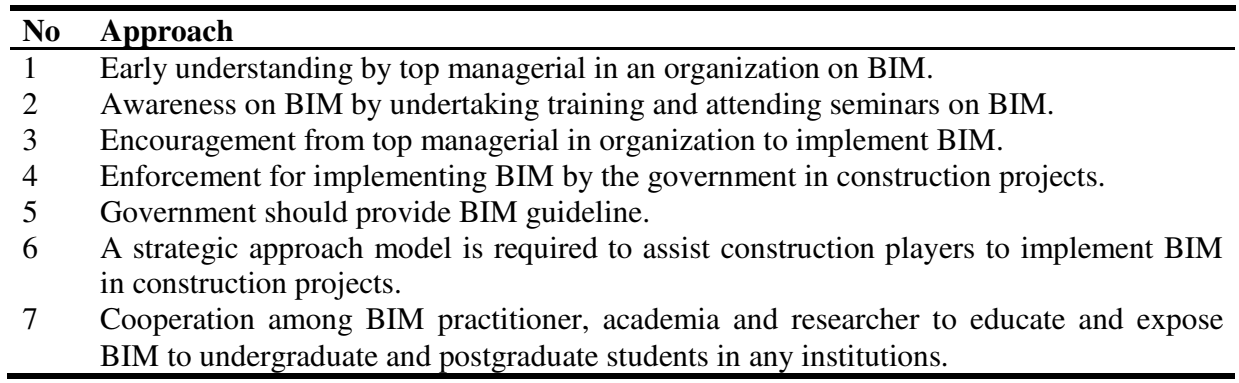

\section{Conclusion and Further Works}

The findings from the interviews revealed that, BIM implementation in construction projects is important to produce a better end product of construction project. Based on the findings, the effects, barriers and challenges of BIM implementation in Malaysian construction projects faced by Malaysian construction players were similar to others countries such as the United Kingdom (UK) and Singapore [7]. Therefore, it can be concluded that, each country will face the same issues in order to implement BIM in their AEC industry.

Apart from that, potential improvement suggested by the respondents was also found similar to others studies. For example, both countries (UK and Singapore) 
highlighted that collaboration between BIM practitioner and government play an important role in order to implement BIM in the construction industry [7]. Apart from that, cooperation between both parties is also important to develop a standardize BIM guideline, which could be used by all construction players in their country [7]. However, this paper also revealed that, the Malaysian construction players need to be guided in order to implement BIM in construction projects or else they will refuse to implement BIM in construction projects. Moreover, collaboration among BIM practitioner, top managerial and government plays significant roles to increase BIM implementation in construction projects. This shows that a synergy between the government and the practitioner is crucial in realizing the implementation of this amazing tool in order to reap its full benefits and potentials in Malaysia and the AEC industry in other countries generally.

All information stated in this paper is useful to the construction players in other countries, which intend to implement BIM in their AEC industry. The information will expose construction players the reality that must be faced by them in order to implement BIM. Moreover, it could also be their guideline in order to avoid any unexpected circumstance along their way to implement BIM. Further work should be made in exploring the approach that could improve the implementation of BIM in construction projects. In order to do so, more interviews and survey can be conducted in order to gain more in-depth information on BIM. The information will be useful to increase BIM implementation in the AEC industry.

Acknowledgments. The authors would like to thank the Ministry of Education of Malaysia (MOE), and the Office of Research, Innovation, Commercialization and Consultancy (ORICC), UTHM, for supporting this research under the Exploratory Research Grant Scheme (Vote No. E029) as well as to the respondents (public and private sectors), which willing to share all information for this paper.

\section{References}

1. Ahmad Latiffi, A., Brahim, J., \& Fathi, M. S.: The Development of Building Information Modelling (BIM) Definition. Applied Mechanics and Materials Vol. 567 (2014) pp 625630. Online available since 2014/Jun/06 at www.scientific.net (C) (2014) Trans Tech Publications, Switzerland doi:10.4028/www.scientific.net/AMM.567.625 (2014)

2. Ding, L., Zhou, Y., \& Akinci, B.: Building Information Modeling (BIM) application framework: The process of expanding from 3D to computable nD. Automation in Construction, 46, 82-93 (2014)

3. Eastman, C., Teicholz, P., Sacks, R., \& Liston, K. BIM Handbook: A Guide to Building Information Modelling (BIM) for Owners, Managers, Designers, Engineers and Constructions. John Wiley and Son Inc, New Jersey (2011)

4. Monteiro, A., \& Martins, J. P. A Survey on Modelling Guidelines for Quanty Takeofforiented BIM-Based Design. Automation in Construction, 35, 238-253 (2013)

5. Wong, A. K. D., Wong, F. K. W., \& Nadeem, A. A Government Roles in Implementing Building Information Modelling Systems. Construction Innovation, 1(1), 61-67 (2009) 
6. Ahmad Latiffi, A., Mohd, S., Kasim, N., \& Fathi, M. S. Building Information Modeling (BIM) Application in Malaysian Construction Industry. International Journal of Construction Engineering and Management, 2(A), 1-6 (2013)

7. Zakaria, Z., Mohamed Ali, N., Tarmizi Haron, A., Marshall-Ponting, A. J., \& Abd Hamid, Z. Exploring the adoption of Building Information Modelling (BIM) in the Malaysian construction industry: A qualitative approach. International Journal of Research in Engineering and Technology, 2(8), 384-395 (2013)

8. Construction Research Institute of Malaysia (CREAM): Issues and Challenges in Implementing BIM For SME's in the Construction Industry. Malaysia. Construction Research Institute of Malaysia (CREAM) (2014)

9. Ahmad Latiffi, A., Mohd, S., Brahim.: Application of Building Information (BIM) in the Malaysian Construction Industry: A story of the First Government Project. Applied Mechanics and Materials, ISSN: 1660-9336 (2014)

10. Ahmad Latiffi, A., Brahim, J., Mohd, S., \& Fathi, M. S.: Building Information Modelling (BIM): Exploring Level of Development (LOD) in Construction Projects. Applied Mechanics and Materials, ISSN: 1660-9336 (2014)

11. Mohd, S., \& Ahmad Latiffi, A.: Building Information Modeling (BIM) application in Construction Planning. In: 7th International Conference on Construction in the 21st Century (CITC-VII), 19-21 December 2013, Bangkok, Thailand (2013)

12. Jabatan Kerja Raya (PWD), Unit Building Information Modelling (BIM). Information on https://www.jkr.gov.my/prokom/index.php?option=com_content\&view=article\&id=84\&It emid $=43$ (visited on $12 / 03 / 2013$ )

13. Mendenhall, M. E., Oddou, G. R., \& Osland, J.: Global leadership: Research, practice, and development. Routledge. Taylor and Francis Group (2013)

14. Kymmell, W. Building Information Modeling: Planning and Managing Construction Projects with 4D CAD and Simulations. United States of America: Mc Graw Hill (2008)

15. Azhar, S., Khalfan, M., \& Maqsood, T. Building information modelling (BIM): now and beyond. Australasian Journal of Construction Economics and Building, 12(4), 15-28 (2012)

16. Carter, G., \& Smith, S. D. Safety hazard identification on construction projects. Journal of Construction Engineering and Management, 132(2), 197-205 (2006)

17. Zhang, P. The affective response model: a theoretical framework of affective concepts and their relationships in the ICT context. MIS Quarterly, 37(1), 247-274 (2013)

18. Haron, A. T. Organisational readiness to implement building information modelling: A framework for design consultants in Malaysia (Doctoral dissertation, University of Salford) (2013)

19. Love, P. E., Matthews, J., Simpson, I., Hill, A., \& Olatunji, O. A. A benefits realization management building information modeling framework for asset owners. Automation in Construction, 37, 1-10 (2014)

20. Furneaux, C. \& Kivit, R. BIM: Implications for Government. CRC for Construction Innovation. Brisbane Australia: Net Pty Ltd (2008)

21. Forbes, L. H. \& Ahmed, S. M. Modern Construction Lean Project Delivery and Integrated Practices. United States of America: Taylor and Francis Group, LLC (2011) 